Vol.9, No.2, pp.49-62, 2021

Print ISSN: 2052-6393(Print),

Online ISSN: 2052-6407(Online)

\title{
THE IMPACT OF HR ANALYTICS BUILDING BLOCKS' ON ORGANIZATIONAL TRIPLE BOTTOM LINE: A CONCEPTUAL PAPER
}

\author{
Salma Dawoud \\ Department of Human Resource Management, Faculty of Commerce, Cairo \\ University, Egypt \\ Professor Gamal M.Shehata \\ Department of Human Resource Management, Faculty of Commerce, Cairo \\ University, Egypt
}

\begin{abstract}
Although the importance of HR Analytics in literature and practice is elevating however the paradox still exists. The articles addressing HR Analytics are still quite limited that resulted in sparse evidence on the topic. Consequently, this is a conceptual paper that aims to figure out if there is a relationship between HR Analytics Building Blocks' and Organizational Triple Bottom line. The study will be using quantitative data through a survey method and a structured survey questionnaire that will be distributed among middle managers of oil and gas service companies operating in the upstream sector in Egypt. The collected data will be analysed using the Structure Equation Modelling (SEM). All kinds of tests will be conducted in order to assure the validity and reliability of the measure.
\end{abstract}

KEYWORDS: HR Analytics, HR Analytics Building Blocks', Triple Bottom Line

\section{INTRODUCTION}

Evidence based management has gained its importance as a discipline in current organizations. In order to ensure a value-add to the business; accurate information, meaningful insights and evidence-based information that is represented in an analytical way are considered key factors to organization success (HCA Group, 2017). In brief, decisions should be based on data, so right choices that positively affect the business can be ensured (Pfeffer \& Sutton, 2006).

HR role has remained vital in linking HR activity to business outcomes and ensuring organization strategy achievement in practice. Over the past decade the focus on HR Analytics has increased steadily as evidenced by the continuously growing demand of adding success to the previous process by gathering HR resources and data to support the business decisions rather than just validating existing knowledge, thus the role of HR Analytics is indispensable for the sake of achieving accurate decisions (Ulrich \& Dulebohn, 2015).

In the shadow of the anticipated importance of HR Analytics; researches are still lagging as they are confined in exploring the importance of HR Analytics application instead of moving forward to exploring the black box in which HR Analytics Building Blocks' contribution might face boundary roles (Marler \& Boudreau, 2017).

In conjunction with the sparse literature on the possible impact of HR Analytics on organization performance such as the impact on the organization Triple Bottom Line. The Triple Bottom Line has gained its importance through being informed by and 
Vol.9, No.2, pp.49-62, 2021

Print ISSN: 2052-6393(Print),

Online ISSN: 2052-6407(Online)

closely related to the concept of sustainability according to Savitz and Weber (2006). As the concept of the Triple Bottom Line secures the essence of sustainability through measuring the practices performed by the organizations on the world.

Despite all the progress and the increase in recognition of how important and valuable HR Analytics is in its impact on organizations, yet there are relatively few researches on HR Analytics and that resulted in sparse evidence on the topic (Marler \& Boudreau, 2017).

This paradox has created and crystalized the paper objective "The integration of HR and Analytics has become extremely spectacular that has resulted in steadily researchers mounting over to study the challenging concept that has linked two divergent conceptions together aiming to investigate the possible impact of such construct on the organization performance illustrated in the triple bottom line.

\section{LITERATURE REVIEW}

\section{Human Resource Analytics}

Given all the various definitions offered, still Levenson, Boudreau and Lawler (2005) are the ones who offer the most comprehensive definition to the HR analytics as they stated that HR analytics can transform the data and measures of HR into a relevant and rigorous insights as it does not only include research design and statistics but also going far and beyond to include other insights of identifying and raising meaningful questions also extended to using the most appropriate and the right standards that can meet the standards leading to rigorous and relevance so eventually it can enhance the analytical competencies needed by the HR inside the organization.

As HR Analytics transforms HR data and measures into rigorous and relevant insights it includes identifying and articulating meaningful questions beside using and gathering data from outside and within the HR function to be rigor and relevant in addition to enhancing analytical competencies of HR (Levenson, Boudreau \& Lawler, 2005). Although the measurement and decision-making processes of $\mathrm{HR}$ is maturing yet considerable uncertainties remain associated and described as the black box of HRM due to the gap between HR initiatives and Return on Investment ROI (Jackson, Schuler \& Jiang, 2014).

As HR Analytics transforms HR data and measures into rigorous and relevant insights it includes identifying and articulating meaningful questions beside using and gathering data from outside and within the HR function to be rigor and relevant in addition to enhancing analytical competencies of HR (Levenson, Boudreau \& Lawler, 2005). Although the measurement and decision-making processes of HR is maturing yet considerable uncertainties remain associated and described as the black box of HRM due to the gap between HR initiatives and Return on Investment ROI (Jackson, Schuler \& Jiang, 2014).

Much has been written about how HR Analytics should be executed in other words the building blocks of HR Analytics. Lawler, Levenson and Boudreau (2004) believe several things are required to perform the type of analytics that show a relationship between HR practices and organizational performance. To begin with, good metrics are required, followed by, and perhaps more importantly, good analytic models and valid 
Vol.9, No.2, pp.49-62, 2021

Print ISSN: 2052-6393(Print),

Online ISSN: 2052-6407(Online)

measures of company performance.

\section{Human Resource Analytics Building Blocks'}

Much has been written about how HR Analytics should be executed in other words the building blocks of HR Analytics. Lawler, Levenson and Boudreau (2004) consider some crucial factors like; solid metrics, solid and clear analytics models and finally a valid organization performance measures. These factors are required in order to implement and put into action the type of analytics that can show the relationship between the HR practices and organizational performance (Van den \& Bondarouk, 2017).

Among all studies that discussed the execution of HR analytics and its building blocks Davenport, Harris and Shapiro (2010) were able to unite the fundamentals needed to building analytical capability in one acronym 'DELTA". Regarding the Data aspect is concerned to ensure reliable data from systems sometimes due to the fragmented systems, processes and capabilities of HR functions it becomes difficult to get consistent and reliable data from the organization.

As for the Enterprise aspect, in order to have a strategic perspective and make best use of analytics; data analysis, integration and processes are essential throughout the enterprise. Moving to the Leadership aspect, it is definite that an effective analytic program has to include the right human capital with analytical competencies and skills in order to succeed. This aspect considers the leaders support as the advocate for a successful HR analytics implementation (Marler \& Boudreau, 2017).

Moving to targeting the right analytical opportunities, the organizations have to be able to define the required and needed type of analytics taking into consideration the availability of HR analytical capability that has to be there for a successful running. Reaching the final aspect which is the Analysts, ensuring existence of methodical approaches to measure and track the HR capabilities, processes and outcomes is one factor. The other important factor is to build and utilize analytical skills through the HR department. The other half is building and using analytical skills throughout the HR Department so that the organization can extract the most value from the data and metrics (Marler \& Boudreau, 2017).

The Deloittes Human Capital Trends (2011) added that it's very important for the organization to start as long as they have data in place stating that if the organization has a payroll system that people are paid accordingly then they have no rationale behind the delay and they have enough data required to begin.

Davenport, Harris and Shapiro (2010) supported the DELTA model declaring that in order for the analytical theory to be applicable organizations need organizational design specialists, psychometrics and human resources systems along with the quantitative abilities. While they also had their slightly different view regarding the HR analytics building blocks although their model compares well with Deloitte's. The model indicates five main aspects; selecting the right people with the right skills, selecting the right process that will impact the decision, selecting the necessary technology, identifying the right ways if getting valuable internal and external data and ensuring governance of data through assigning accountable personnel responsible for the 
Vol.9, No.2, pp.49-62, 2021

Print ISSN: 2052-6393(Print),

Online ISSN: 2052-6407(Online)

implementation.

\section{Triple Bottom Line}

Back to 1990s, John Elkington was the first to coin the term Triple Bottom Line as a consistent construct were the three elements must be included in any performance evaluation aiming to explore and describe the financial, environmental and social investment value adding that may go beyond the financial bottom line of the organization (Elkington, 2004). The concept according to Roberts and Cohen (2002) is often referred to as Triple Value Adding and it's also referred to as the 3Ps People, Planet and Profit or the blended value (Emerson, 2003). The importance of the concept is due to its vital role in aiming more accurate value assets and leverage resources in order to ensure efficiency and effectiveness of capital (Emerson, 2003).

Since sustainability became a powerful and important concept in the business world and being a sustainable organization ensures that as much as the organization care for creating profits to the stakeholder it has to give the same attention to protect the environment where they are operating as well as the lives of whoever involved in the process (Slaper and Hall, 2011) in addition to ensuring that the development will not affect the opportunities and needs of future generations (World Commission on Environment and Development, 2013). Businesses are currently giving a huge consideration to sustainability practices, Savitz and Weber (2006) argued that it's a mean for organizations to achieve increase its profitability. Therefore, the Triple Bottom Line has gained its importance through being informed by and closely related to the concept of sustainability. According to Savitz and Weber (2006) the concept of Triple Bottom Line secures the essence of sustainability through measuring the practices performed by the organizations on the world.

In spite of the fact that organizations in business world are now incorporating the Triple Bottom Line thinking into their reports and despite the importance of the balance offered by the Triple Bottom Line and that drives organizations to sustainability (Adams \& Frost, 2008). Research regarding how businesses understand, prioritize and act upon the Triple Bottom Line concept is sparse (Hammer \& Pivo, 2016) and still scholars assign sustainability to the environmental category and this justifies the few numbers of researches on the essence of sustainability as a driver to performance and profitability (Rodriguez, Svensson, \& Eriksson, 2018).

\section{Evolution of Conceptual Model and Hypotheses Development}

The evolution of the research conceptual model is originated through identifying evidently the main problem the research was based upon via tracking the gaps involved that validate the problem and also through identifying the importance of choosing each variable in the model. Moving to the second step after identifying how the model was evolved which is the development of the research hypotheses and to what extent the researcher has succeeded in building strong, evidence based hypotheses that can compels thinking intensely and specifically about the outcomes of the study also to what extent these developed hypotheses enable in understanding the implications of the research questions and the different variables involved in the topic under study. 
Vol.9, No.2, pp.49-62, 2021

Print ISSN: 2052-6393(Print),

Online ISSN: 2052-6407(Online)

\section{Evolution of Conceptual Model}

The research model is developed in a way that reflects interrelationships among its concepts that are originally based on a clear gap or problem that has led to the evolution of the model. In the case of this study there were huge set of derivers triggering the evolution of the current conceptual model presented in this research. Starting with the reason behind choosing the HR analytics to be studied is the sparse literature on Human Resource Analytics in general along with the number of empirical researches carrying out the application of the topic in emerging countries are also very few ( Zeidan \& Etani, 2020).

As the area of HRA has witnessed little development over time starting from the Incubation during the period of 2000 to 2005, as 4\% of the HR Analytics research was published. The second phase was during the period of 2006 to 2010 which can be classified as an incremental growth as $10 \%$ of the HR analytics researches were published. Moving to the last stage which can be named as the substantial growth phase during the period 2011 to 2016 as $86 \%$ of HRA articles was published. And although the research attention devoted to HR analytics has increased in recent years yet still the literature and the empirical evidence of HRA is relatively lagging (Ben-Gal, 2019).

The majority of researches on HR analytics are tackling the topic from the adoption perspective and mostly ignoring the building blocks of HR analytics that is considered to be more applicable and mostly needed especially when we talk about a new concept such as the concept of HR analytics and how it could be successfully utilized so it can show its pay off and its effect of organization (Sripath \& Madhavaiah, 2018).

Consecutively academics as well as practitioners have to feel the necessity to invest in this development if HR does not want to lose its ground. The importance of HR Analytics is progressively being recognized and organizations are starting to invest in data metrics and analytics in HR, but they still need to make sure it will work. (Marler \& Boudreau, 2017).

In regards to choosing the Triple Bottom Line variable although it has gained its importance through being informed by and closely related to the concept of sustainability according to Savitz and Weber (2006). Yet the literature and application on the topic is still lagging relative to the importance that was proved it has on organizations. Besides the effect the concept has on the world through securing the essence of sustainability by measuring the practices performed by the organizations (Hernik \& Minguez, 2017)

Consistently businesses will not invest if this will not pay off, organizations in practice always keep an eye on their bottom line because this is what keeps them sustainable, such insights are important from a theoretical point of view; no researches tackled the impact of HR Analytics on the Triple Bottom Line as a stand-alone concept instead the researches have discussed the impact HR analytics has on each dimension in the TBL separately (Rodriguez, Svensson, \& Eriksson, 2018).

Although the current research model consists of multiple variables that were tested to be valid and shown their effect and importance in different contexts yet no apparent researches have studied the effect of HR analytics on Triple bottom line instead the 
Vol.9, No.2, pp.49-62, 2021

Print ISSN: 2052-6393(Print),

Online ISSN: 2052-6407(Online)

studies involved the effect of HR analytics on each dimension in the TBL separately and not collectively under the name and the concept of TBL which indicates that the performance should be all the three together giving the same weight of importance to the three dimensions and still these articles are very few.

Another strain of literature measures the impact of HR analytics on the concept of performance in general which includes inside the three dimensions but again not with the same paradigm of the TBL and not with the equal weight among the dimensions of the TBL (Hamilton \& Sodeman, 2020). Therefore it became important to have a model that involves these variables in order to test the relationship between them and assess their theoretical and practical implications aiming to add a valid contribution to both aspects.

\section{Hypotheses Development}

As the research usually starts with a significant and apparent problem and then this problem is usually translated to questions and hypotheses so the researcher tracks the questions and verify the validity and testability of these hypothesis until the answer is reached and the contribution is achieved. Developing a good hypothesis requires a clear explanation to the relationships between the measurable variables included in the model and that accounts for a set of facts also it has to provide a clear explanation of the topic under study in order to facilitate the extension of knowledge in a specific area.

A direction in HR analytics research has been supporting the relationship between HR analytics as a concept and the dimensions of the triple bottom line through clarifying the concept of decision making which is incorporated in and also the core reason behind the utilization of the HR analytics concept. As the existence of the HR analytics perspective is coming out of the idea that the existence of the data enhances the decision making process and since the triple bottom line is all about the organization outcomes therefore the decision making process is crucial in leading to these three outcomes (Cochran, 2014) (Janssen, Voort \& Wahyudi, 2017).

Many others have emphasized on using HR analytics for effective organizational processes that involves incorporating HR analytics as an effective decision-making support tool (Dulebohn \& Johnson, 2013; Singh \& Roushan, 2013; Holsapple et al., 2014; Chamorro-Premuzic et al., 2017).

Moreover Sharma, Mithas \& Kankanhalli (2014) in their article "Transforming decision-making processes: a research agenda for understanding the impact of business analytics on organizations" have also reached the same conclusion. Furthermore Minbaeva and Collings (2013) and Pape (2016) in their article "The role of HR Analytics in improving organizational decision making" found that there is a strong positive impact of the HR analytics on improving the organization decision making in while similarly Ghasemaghaei, Ebrahimi and Hassanein (2017) have proved that data analytics competency improves firm decision making performance.

On the other hand it was verified and proved that when HR departments rely put HR analytics into action this result in a higher ability from the organization side to achieve a competitive advantage considering the role of decision making (Kapoor \& Sherif, 2012; Sparrow, 2012; Fulmer \& Ployhart, 2014). Parallel to this Schulz and Flanigan 
Vol.9, No.2, pp.49-62, 2021

Print ISSN: 2052-6393(Print),

Online ISSN: 2052-6407(Online)

(2016) have confirmed that using triple bottom line creates competitive advantage through the role of effective decision making. Other studies have also studied the same perspective asking if $\mathrm{HR}$ analytics is associated with or can cause better performance and competitive advantage when it is unique and value producing as their hypotheses were proved (Coco, Jamison \& Black, 2011; Douthitt \& Mondore, 2014; Mondore et al., 2011; Rasmussen \& Ulrich, 2015).

Another stain of literature has supported the relationship between the two variables; HR analytics and triple bottom line by studying the effect of HR analytics on performance in general and that also incorporates the outcomes integrated in the triple bottom line like a study done by Samuel (2018) which confirms that perceived technology, talent and information quality are significant determinants of the quality of big data analytics and it also identifies an alignment between analytics quality and firm strategy moderating the relationship between the quality of big data analytics and firm performance.

Many researchers have also studied the relationship between HR analytics and organization performance from a close perspective to the concept of the triple bottom line proving the strong impact HR analytics have on performance (Akter, Wamba, Gunasekaran, Dubey \& Childe, 2016) in their article "How to improve firm performance using big data analytics capability and business strategy alignment". Hitt and Kim (2011) in their article "How does data-driven decision-making affect firm performance". In addition to a study by Ghasemaghaei (2018) under the title "Improving organizational performance through the use of big data" where it was proved that there is a strong positive impact between the two variables.

In much of the business research, big data analytics was proved to be a new opportunity to enhance productivity, efficiency and innovation in companies (Sheng et al., 2017; Verma and Bhattacharyya, 2017; Connelly et al., 2016; Marshall et al., 2015; VeraBaquero et al., 2015; Ajana, 2015; Dagiliene \& Kloviene, 2019). Despite of the strong evidence based insights towards the elevating importance of HR analytics and the impact it has on the performance of the organizations yet still organizations legging behind in terms of investing in this matter concurrently, researches investigating this relationship are also sparse (Marler \& Boudreau, 2017). Finally it can be concluded that HR Analytics is about linking HR decisions to business outcomes and organizational performance, accordingly the following hypothesis can be concluded.

\section{There is a relationship between HR Analytics Building Blocks' and organizational Triple Bottom Line}

The development of this sub hypothesis was based on multiple researches; one of these researches has examined the extent of sustainable capabilities driven by corporate commitment that is resulting from the integration of big data technologies, green supply chain management, and green human resource management practices considering the extent to which these capabilities can help in enhancing the broader organization performance. It recognized that green human resource management practices and big data management can enhance firms' sustainable capabilities and that eventually can lead to a better sustainable performance (Singh\& El-Kassar, 2018).

On the other hand an article by Wasylka (2018) under the title "A new tool for the 
Vol.9, No.2, pp.49-62, 2021

Print ISSN: 2052-6393(Print),

Online ISSN: 2052-6407(Online)

evaluation of the analytical procedure: Green Analytical Procedure Index" has recommended a specific symbol with five pentagrams that can be used to evaluate and quantify the environmental impact involved in each step of an analytical methodology which again embraces the relationship between HR analytics and organizational environmental performance.

Ha: There is a relationship between HR Analytics Building Blocks' and organizational environmental performance

The development of this sub hypothesis is coming from gained importance of this dimension as previously literature and practical directions were always towards the financial aspect and how much any practice will pay of sub-sequentially the importance of the effect of organization practices on environment has arisen afterwards the social performance mounted over reflecting the crucial importance of existence on the organization and the effect of the organization practices on it. As a result the concept of the triple bottom line was evolved with giving a great and equal importance to the three dimensions (Chae, Yang, Olson \& Sheu 2014).

This view was also supported by Gond \& Crane (2010) in their article "Corporate social performance disoriented: Saving the lost paradigm”. Emphasizing on the same point; HR analytics were proved by Mayo (2018) that t greatly contributes in defining the talents and understanding their potential through some metrics that helps in utilizing talents. It was also proved by many studies that HR analytics aims to gain insight and support decision making processes with regard to managing people in organizations (Fitz-enz, 2000; Handa \& Garima, 2014; Zhao \& Carlton, 2015).

It has been also acknowledged that HR analytics has transformed the way HR processes are managed in terms of how the organizations collect, store, use and disseminate information about applicants and employees (Stone et al., 2015). While Bassi (2011) argued that it's an evidence-based approach for making better decisions on the people side of the business. Others have portrayed the importance of HR analytics in controlling decisions related to the social aspect and leading to continuous improvement (Levenson, 2005; Levenson, 2015; Newcomer \& Brass, 2015; Welbourne, 2015). On the other side some studies have based their researches on the existence of this relationship and proceeded with the future challenges in order to make it successful like for example the analytic tools that would be correct to adopt for a specific group of people and which form of technology to use better (Marler and Boudreau, 2017; Strohmeier, 2018).

\section{Hb: There is a relationship between HR Analytics Building Blocks' and Perceived organizational social performance}

This sub hypothesis was developed based on the paradigm of most of the researches linking HR analytics to the most recognized concept of bottom line which is the financial performance as it can be considered one of the most important aspects if not the most important that the organization track for the sake of business survival. Many researches have tackled this relationship considering the role of decision making in generating business financial outcomes (Wamba et al., 2015).

A study by Momin \& Mishra (2015) under the title "Impression of Financial Measures 
Vol.9, No.2, pp.49-62, 2021

Print ISSN: 2052-6393(Print),

Online ISSN: 2052-6407(Online)

in HR Analytics" and another study by Mondore, Dauthitt and Carson (2011) have indicated that the effectiveness of HR analytics maximizes the impact it has on financial business results. Another empirical study has provided a strong evidence on the relationship between HR analytics and the organization financial performance pointing on the a cause and effect relationship between the two variables specifying that organizations use a combination of pay for performance and human capital software so $\mathrm{HR}$ analytics are the most productive because this combination allows the alignment of incentives and also allows the manager to monitor the employees behavior.

Hc: There is a relationship between HR Analytics Building Blocks' and organizational financial performance

\section{METHODOLOGY}

The study intends to test the hypotheses on oil and gas service companies operating in the upstream sector in Egypt. Data will be collected using a self-administrated questionnaire except for the part related to the financial dimension as it will be provided by the organization annual reports. The questionnaire will be distributed among all the middle managers in the four organizations that acquire the market share.

The collected data will be analyzed using the Structure Equation Modeling (SEM) because it estimates the multiple and interrelated dependence in a single analysis. All Scales are subject of testing the reliability via; Cronbach's Alfa and the validity via; construct validity, convergent validity and discriminant validity. Also a T-test will be conducted to test if the sample means which is an estimate of the population mean is differ significantly from the given population mean and an F-Test will be conducted to determine the variance within the sample.

\section{CONCLUSIOON}

Although the importance of HR Analytics in literature and practice is elevating however the paradox still exists. The articles addressing HR Analytics are still quite limited. However, the relevance of the topic and the very few numbers of organizations that examined the long-term impact of HR Analytics on their performance or operations might be a reason of limited literature on the topic (Scheimann, 2018). Thus the literature has to expand the boundaries of knowledge on HR Analytics due to the great contribution this area will add to the Human Resources field.

Consistently businesses will not invest if this will not pay off, organizations in practice always keep an eye on their bottom line because this is what keeps them sustainable, such insights are important from a theoretical point of view; no researches tackled the impact of HR Analytics on the Triple Bottom Line (Rodriguez, Svensson, \& Eriksson, 2018).

Studies of other HR topics shows a huge gap between scholar and practice where scholars are so far lagging. This case is not applicable in HR Analytics area as the lagging in this area is in both literature and practice which will need more efforts in disclosing the area of analytics. This is a huge opportunity on ground for scholars and researchers to start a new phase in developing HR in practice speak the business language and go beyond the boundaries of literature (Ulrich \& Dulebohn, 2015). 
Vol.9, No.2, pp.49-62, 2021

Print ISSN: 2052-6393(Print),

Online ISSN: 2052-6407(Online)

Academics as well as practitioners have to feel the necessity to invest in this development if HR does not want to lose its ground. The importance of HR Analytics is progressively being recognized and organizations are starting to invest in data metrics and analytics in HR, but they still need to make sure it will work. (Marler \& Boudreau, 2017).

\section{REFERENCES}

Adams, C. A., \& Frost, G. R. (2008). Integrating sustainability reporting into management practices. Accounting Forum, 32(4), 288-302. doi:10.1016/j.accfor.2008.05.002.

Ajana, B. (2015) "Augmented borders: Big Data and the ethics of immigration control", Journal of Information, Communication and Ethics in Society, Vol. 13 Iss: 1, pp. $58-78$

Akter, S., Wamba, S. F., Gunasekaran, A., Dubey, R., \& Childe, S. J. (2016). How to improve firm performance using big data analytics capability and business strategy alignment? International Journal of Production Economics, 182, 113131. https://doi.org/10.1016/j.ijpe.2016.08.018

Alejandro Vera-Baquero Ricardo Colomo Palacios Vladimir Stantchev Owen Molloy , (2015),"Leveraging big-data for business process analytics", The Learning Organization, Vol. 22 Iss 4 pp. $215-228$

B.K. Chae, C. Yang, D. Olson, C. Sheu, The impact of advanced analytics and data accuracy on operational performance: a contingent resource based theory (RBT) perspective, Decision Support Systems 59 (2014) 119-126.

Bassi, L. (2011). Raging Debates in HR Analytics. McBassi and Company. People and Strategy. $34(2$

Ben-Gal, H. C. (2019). An ROI-based review of HR analytics: practical implementation tools. Personnel Review, 48(6), 1429-1448.

Bi, Z., Cochran, D.: Big data analytics with applications.Journal of Management Analytics 1(4) (2014) 249-265.

Brynjolfsson, E., Hitt, L. M., \& Kim, H. H. (2011). Strength in Numbers: How does data-driven

Buss, W. C. and Kuyvenhofen, R. K. (2011), 'Perceptions of European Middle Managers of their Role in Strategic Change', Global Journal of Business Research, Vol. 5, No. 5, pp. 109-119.

Chamorro-Premuzic, T., Akhtar, R., Winsborough, D. and Sherman, R.A. (2017), "The datafication of Q17 talent: how technology is advancing the science of human potential at work", Current Opinion in Behavioral Sciences, No. 18, pp. 13-16.

Coco, C. T., Jamison, F., \& Black, H. (2011). Connecting people investments and business outcomes at Lowe's: Using value linkage analytics to link employee engagement to business performance. People and Strategy, 34(2), 28-33. Retrieved from https://www.hrps.org

Connelly, R, Playford, C, Gayle, V \& Dibben, C 2016, 'The Role of Administrative Data in the Big Data Revolution in Social Science Research', Social Science Research, vol. 59, no. September 2016, pp. 1-12. https://doi.org/10.1016/j.ssresearch.2016.04.015 
Vol.9, No.2, pp.49-62, 2021

Print ISSN: 2052-6393(Print),

Online ISSN: 2052-6407(Online)

Davenport, T. H., Harris, J., Shapiro, J. (2010). Competing on talent analytics. Harvard Business Review.

Deloittes Human Capital Trends (2011). Workforce Analytics: Up the ante.Revolution/Evolution. Deloitte Development LLC. Department of Strategic Management and Globalization

Douthitt, S., \& Mondore, S. (2014). Creating a business-focused HR function with analytics and integrated talent management. People \& Strategy, 36, 16-21.

Dulebohn, J.H. and Johnson, R.D. (2013), "Human resources metrics and decision support: a classification framework", Human resources Management Review, Vol. 23 No. 1, pp. 71-83.

Elkington, J. (2004). Enter the Triple Bottom Line. In A. Henriques \& J. Richardson (Eds.), The Triple Bottom Line: Does it all add up? (pp. 1-16). London, England: Earthscan.

Emerson, J. (2003). The blended value proposition: Integrating social and financial returns. California Management Review, 45, 35-51.

Fitz-Enz, Jac. (2000), The ROI of Human Capital, Amacom, New York.

Fulmer, I.S. and Ployhart, R.E. (2014), "Our most important asset: a multidisciplinary/multilevel review of human capital valuation for research and practice", Journal of Management, Vol. 40 No. 1, pp. 161-192.

Gond, J.-P., A. Crane. 2010. Corporate social performance disoriented: Saving the lost paradigm? Business \& Society, forthcoming.

Hamilton, R., \& Sodeman, A. (2020). The questions we ask: Opportunities and challenges forusing big data analytics to strategically manage human capital resources. Business Horizons, 63(1), 85-95.

Hammer, J. \& Pivo, G. (2016). The Triple Bottom Line and Sustainable Economic Development Theory and Practice. Economic Development Quarterly, 1-12.

Handa, D. \& Garima. (2014). Human Resource (HR) Analytics: Emerging Trend in HRM, International Journal of in Commerce \& Management, 5(6). Retrieved from www.ijrcm.org.in

HCA Group (2017). insights. Retrieved from https://www.cbs.dk/en// departmentsand-centres/department-of-strategic-management-and-globalization/humancapital-analytics/publications/-insights.

Hernik, J., Minguez Vera, A. (2017), "Searching for a Perfect Composition for a Board of Directors", Journal of Corporate Responsibility and Leadership, Vol. 4, Issue 1, pp. 19-38.

Holsapple, C., Lee-Post, A. and Pakath, R. (2014), “A unified foundation for business analytics”, Decision Support Systems, Vol. 64, pp. 130-141.

Jackson, S., Schuler, R. \& Jiang, K. 2014. An aspirational framework for strategic human resource management. The academy of management annals. 8, 1: 1-56.

Juan Zhang, Xiongsheng Yang, and Deniz Appelbaum, 2015, "Toward Effective Big Data Analysis in Continuous Auditing", Accounting Horizons, Vol. (29), No. (2), PP. 469-476.

Kapoor, B., \& Kabra, Y. (2014). Current and future trends in human resources analytics adoption. Journal of Cases on Information Technology, 16, 50-59. doi:10.4018/jcit.2014010105 
Vol.9, No.2, pp.49-62, 2021

Print ISSN: 2052-6393(Print),

Online ISSN: 2052-6407(Online)

Lawler, E. E., Levenson, A., \& Boudreau, J. (2004). HR Metrics and Analytics Uses and Impacts. CEO Publication - Working Paper. Retrieved February 23, 2012 from http://classic.marshall.usc.edu/ assets/048/9984.pdf

Levenson, A. (2005), "Harnessing the power of HR analytics", Strategic HR Review, Vol. 4 No. 3, pp. 28-31.

Levenson, A., Lawler III, E. E., \& Boudreau, J. W. (2005). Survey on HR Analytics and HR transformation: Feedback report. Los Angeles, CA: Center for Effective Organizations, University of Southern California.

Levenson, A., Lawler III, E. E., \& Boudreau, J. W. (2005). Survey on HR Analytics and HR transformation: Feedback report. Los Angeles, CA: Center for Effective Organizations, University of Southern California.

Lina Dagiliene \& Lina Kloviene, 2019. "Motivation to use big data and big data analytics in external auditing," Managerial Auditing Journal, Emerald Group Publishing, vol. 34(7), pages 750-782, July.

M. Ghasemaghaei, Improving organizational performance through the use of big data, Journal of Computer Information Systems (2018) 1-14.

M. Ghasemaghaei, S. Ebrahimi, K. Hassanein, Data analytics competency for improving firm decision making performance, The Journal of Strategic Information Systems 27 (2017) 101-113.

M. Janssen, H. van der Voort, A. Wahyudi, Factors influencing big data decisionmaking quality, Journal of Business Research 70 (2017) 338-345.

Marler, J. H. \& Boudreau, J. W. (2017). An evidence-based review of HR Analytics. International Journal of Human Resource Management, 28(1), 3-26.

Marshall, J., J.R. Scott, K.C. Armour, J.-M. Campin, M. Kelley, and A. Romanou, 2015: The ocean's role in the transient response of climate to abrupt greenhouse gas forcing. Clim. Dyn., 44, no. 7-8, 2287-2299, doi:10.1007/s00382-014-23080 .

Mayo, A. (2006). Measuring and reporting: The fundamental requirement for data. CIPD. Report. Retrieved January 17, 2012 from http://www.mayolearning.com/mayo-publications/

Minbaeva, D., \& Collings, D. G. (2013). Seven myths of global talent management.

Minbaeva, D., \& Collings, D. G. (2013). Seven myths of global talent management. The International Journal of Human Resource Management, 24(9), 1762-1776.

Momin, W. Y. M. (2015). HR analytics transforming human resource management. International Journal of Applied Research, 1, 688-692. Retrieved from http://www.allresearchjournal.com

Mondore, S., Douthitt, S., Carson, M. (2011). Maximising the Impact and Effectiveness of HR Analytics to Drive Business Outcomes. Strategic Management Decisions. People and Strategy. 34 (2).

Mondore, S., Douthitt, S., Carson, M. (2011). Maximising the Impact and Effectiveness of HR Analytics to Drive Business Outcomes. Strategic Management Decisions. People and Strategy. 34 (2).

Newcomer, K. and Brass, C.T. (2015), "Forging a strategic and comprehensive approach to evaluation within public and nonprofit organizations: integrating measurement and analytics within evaluation", American Journal of Evaluation, 1098214014567144. 
Vol.9, No.2, pp.49-62, 2021

Print ISSN: 2052-6393(Print),

Online ISSN: 2052-6407(Online)

Pape, T. (2016). Prioritising data items for business analytics: Framework and application to human resources. European Journal of Operational Research, 252, 687-698.

Pfeffer, J., \& Sutton, R. I. (2006). Hard facts, dangerous half-truths, and total nonsense: Profiting from evidence-based management. Harvard Business School Press.

Płotka-Wasylka, J. (2018). A new tool for the evaluation of the analytical procedure: Green Analytical Procedure Index. Talanta, 181, 204-209. https://doi.org/10.1016/j.talanta.2018.01.013

Rasmussen, T., \& Ulrich, D. (2015). Learning from practice: How HR Analytics avoids being a management fad. Organizational Dynamics.

Roberts, B., \& Cohen, M. (2002). Enhancing sustainable development by triple value adding to the core business of government. conomic Development Quarterly, $16,127-137$.

Roberts, B., \& Cohen, M. (2002). Enhancing sustainable development by triple value adding to the core business of government. conomic Development Quarterly, $16,127-137$.

Rocio Rodriguez, Goran Svensson, David Eriksson, (2018). "Organizational logic to prioritize between the elements of Triple Bottom Line", Benchmarking: An International Journal, Vol. 25 Issue: 6, pp.1626-1640, https://doi.org/10.1108/BIJ-02-2017-0027

Rocio Rodriguez, Goran Svensson, David Eriksson, (2018). "Organizational logic to prioritize between the elements of Triple Bottom Line", Benchmarking: An International Journal, Vol. 25 Issue: 6, pp.1626-1640, https://doi.org/10.1108/BIJ-02-2017-0027

S.F. Wamba, S. Akter, A. Edwards, G. Chopin, D. Gnanzou, How 'big data' can make big impact: findings from a systematic review and a longitudinal case study, International Journal of Production Economics 165 (2015) 234-246.

Samuel Fosso Wamba, Shahriar Akter, Marc de Bourmont, (2018) "Quality dominant logic in big data analytics and firm performance", Business Process Management Journal, https://doi.org/10.1108/ BPMJ-08-2017-0218

Sanjay Kumar Singh a, Abdul-Nasser El-Kassar, (2018) Role of big data analytics in developing sustainable capabilities: Journal of Cleaner Production 213 (2019) $1264 \mathrm{e} 1273$

Savitz, A., Weber, K. (2006). The Triple Bottom Line: how today's best-run organizations are achieving economic, social and environmental success- and how you can too. San Francisco: Jossey-Bass.

Savitz, A., Weber, K. (2006). The Triple Bottom Line: how today's best-run organizations are achieving economic, social and environmental success- and how you can too. San Francisco: Jossey-Bass.

Schiemann, W. A., Seibert, J. H., \& Blankenship, M. H. (2018). Putting human capital analytics to work: Predicting and driving business suc- cess. Human Resource Management

Sharma, R., Mithas, S., \& Kankanhalli, A. (2014). Transforming decision-making processes: A research agenda for understanding the impact of business analytics on organisations. European Journal of Information Systems, 23, 433-441. doi:10.1057/ejis.2014.17 
Vol.9, No.2, pp.49-62, 2021

Print ISSN: 2052-6393(Print),

Online ISSN: 2052-6407(Online)

Singh, N.K. and Roushan, R.K.S. (2013), "Data analytics and decision support in the context of ERP and beyond for giving CSIR a competitive advantage - two case studies from HR (Human resources) and MM (Materials Management) modules".

Slaper, T., F., Hall, T., J. (2011). The Triple Bottom Line: What Is It and How Does It Work?. Indiana Business Review, 86 (1), 4-8. Indiana University Kelley School of Business, Indiana Business Center.

Sparrow, P.R. (2012) Globalising the international mobility function: the role of emerging markets, flexibility and strategic delivery models. International Journal of Human Resource Management, 23 (12): 2404-2427

Sripathi, K., \& Madhavaiah, C. (2018). Are HR professionals ready to adopt HR analytics? A study on analytical skills of HR professionals. Journal of Advanced Research in Dynamical and Control Systems 10(8), 303-308.

Stone, G. A. \& Duffy, L. N. (2015). Transformative Learning Theory: A Systematic Review of Travel and Tourism Scholarship. Journal of Teaching in Travel and Tourism, 15(3), p. 204-224, DOI: 10.1080/15313220.2015.1059305.

Strohmeier, S. (2018), "Smart HRM - a Delphi study on the application and consequences of the Internet of things in human resource management", The International Journal of Human Resource Management, pp. 1-30.

The International Journal of Human Resource Management, 24(9), 1762-1776.

The World Commission on Environment and Development. Our Common Future: Report of UN Documents. n.d. Web. Retriev ed 27 June 2013. < http://www.undocuments. net/ocf-02.htm>

Ulrich, D. \& Dulebohn, J. 2015. Are we there yet? What's next for HR? Human Resource Management Review. 25: 188-204.

Ulrich, D. \& Dulebohn, J. 2015. Are we there yet? What's next for HR? Human Resource Management Review. 25: 188-204.

Van den Heuvel, S. and Bondarouk, T. (2017), "The rise (and fall?) of HR Analytics: a study into the future application, value, structure, and system support", Journal of Organizational Effectiveness: People and Performance, Vol. 4 No. 2, pp. 157178.

Verma, S. and Bhattacharyya, S.S. (2017), "Perceived strategic value-based adoption of Big Data Analytics in emerging economy: A qualitative approach for Indian firms", Journal of Enterprise Information Management, Vol. 30 No. 3, pp. 354382. https://doi.org/10.1108/JEIM-10-2015-0099

Zeidan, S. and Itani, N. (2020). HR Analytics and Organizational Effectiveness. International Journal on Emerging Technologies, 11(2): 683-688.

Zhao, G. and Carlton, D. (2015) Forecast Competency Migration by a Methodology of Competency Analytics. Open Journal of Social Sciences, 3, 16-22. http://dx.doi.org/10.4236/jss.2015.311003 